\section{Saving the tiger in the wild}

SIR - Until recently, the major threat to wild tiger populations was declining habitat. Operation Tiger. started in 1973, has been experiencing some success in reducing this threat by creating tiger reserves throughout India and Nepal. However, since 1991. poaching (to provide bones for traditional Chinese medicine) has increased dramatically. to the point where persistence of wild tiger populations may once more be in question. According to a recent report. China exported more than 15.000 cartons of tablets, $5.000 \mathrm{~kg}$ of confections, and 31.000 bottles of wine containing tiger bone as an ingredient in 1991 alone. Because few wild tigers remain in China, most bone is imported, primarily from the Indian subcontinent.

Anecdotal information indicates the seriousness of this new threat. It is important. however. to provide a quantitative basis for strong policy action. We therefore created a tiger simulation model to explore the effects of poaching on population viability. The model is an individualbased stochastic spatial model, developed according to the extensive data set from Royal Chitwan National Park, Nepal. Our initial results suggest that, as poaching continues over time, the probability of population extinction increases sigmoidally; a critical zone exists where a small incremental increase in poaching greatly increases the probability of extinction.

Tiger poaching has been a worldwide phenomenon for about three years (199194). We found that poaching for this length of time generally results in low probabilities of extinction, except at very high levels of poaching ( 15 tigers a year). This high level of poaching may have occurred at Ranthambhore Tiger Reserve in India where the population is said to have declined from 44-46 tigers in 1991 to 15-20 tigers in 1992. In our model, this level of poaching leads to a $70-90$ per cent probability of extinction.

The next three years (1994-97), however, will be critical for tiger conservation, especially for smaller populations. Approximately 95 per cent of the remaining tiger populations throughout the world consist of fewer than 120 tigers. For these populations, three additional years of a low level of poaching ( 5 tigers a year) leads to a probability of extinction of less than 5 per cent, but if poaching has been and continues to be moderate (10 tigers a year), the probability of extinction is more than 95 per cent. This illustrates dramatically how a small increase in poaching can lead to a much greater probability of extinction. Given the dire consequences of moderate to high levels of poaching and the relative ease with which tigers are poached, it is imperative that we act quickly to strengthen the already con- siderable efforts to reduce poaching.

Successful anti-poaching efforts must include a systematic and objective method to assess accurately the size and the geographic distribution of individual tiger populations. After 20 years of research and management under Operation Tiger, the sizes of individual populations and the extent of contiguous habitat that they occupy are not known anywhere except in Nepal. Tiger habitat distribution maps combined with local density estimates would be an objective method to estimate individual population sizes. A coordinated international effort is once again essential to save the tiger in the wild.

John S. Kenney

Conservation of Biology Program,

James L. David Smith

Department of Fisheries and Wildlife,

Anthony M. Starfield

Department of Ecology,

Evolution, and Behavior,

University of Minnesota,

St Paul, Minnesota 55108, USA

Charles W. McDougal

Tiger Tops Ltd,

PO Box 242,

Kathmandu, Nepal

\section{Vatican error}

SIR - You report (Nature 368, 90; 1994) the Vatican's announcement that the Pope intends to create a Pontifical Academy for Life to provide counsel on ethical matters concerning biology and medicine. The concept of such an institution, consisting of 70 members to be nominated by the pontiff, appears noble and worthwhile, but the requirement that each member must embrace the view that "life begins at the moment of conception" is problematic.

Inasmuch as the process of conception requires the fertilization of a living ovum by a living sperm, no de novo life arises from the process of conception. Rather, life exists before conception (in each of the individual germ cells), it exists during the process of a successful conception and it continues after conception, barring naturally occurring or artificially induced abortion.

To say that "life begins at the moment of conception" is quite different from supporting the view that "life exists before, during and after the moment of conception". The first statement posits "spontaneous creation of life" to explain how such a phenomenon could occur while the latter statement does not.

It would be a shame if competent nominees for the Pontificial Academy for Life were screened out in favour of less qualified ones, but it seems that a poten- tially worthy and important new edifice is being constructed on a defective foundation.

\section{Gerard F. LeBlond}

Biochemistry Department,

School of Hygiene and Public Health,

Johns Hopkins University,

615 North Wolfe Street,

Baltimore, Maryland 21205, USA

\section{Early astronomy}

SIR - Ziauddin Sardar, in reviewing Toby Huff's The Rise of Early Modern Science: Islam, China and the West (Nature 368, 376-378; 1994), suggests that the Dogon knew many astronomical observations 1,500 years earlier than Galileo. He claims that they pose problems for an "emerging new strain of deep Eurocentrism".

They do not, as they never existed. The 'Dogon astronomical observations' are a case of misanthropology like that propounded by Margaret Mead. Their originator was Marcel Griaule, a French anthropologist who had studied astronomy in Paris. Griaule was strongly 'antieurocentric', seeking evidence in Africa to show that non-European societies had produced cultures with thought as sophisticated as that of Europe. And, of course, he 'found' it. While he was studying Dogon secret societies, his informants picked up on his interest in astronomy and told him what he wanted to hear. All was exposed by W. Van Beek a few years ago in Current Anthropology (32, 139-167; 1991).

John R. Skoyles

6 Denning Road,

London NW3 1SU, UK

\section{Eastward in Eden}

SIR - I noted with interest your photograph of Amorphophallus titanum at "a botanical garden" in Indonesia (Nature 368, 399; 1994).

The garden in question is Bogor Kebun Raya, founded in 1817 , which is internationally famous and by far the best of the botanical gardens in South-East Asia. This garden and its diligent staff are relatively poorly funded by the environmentally unsympathetic Indonesian government and the garden is frequently under threat of development. It is therefore a pity to waste an opportunity to advertise its importance.

If this spectacular flower had been blooming in Kew Gardens, would you have said "in a botanical garden in London"? I doubt it.

\section{Chris Reid}

Division of Botany and Zoology,

Australian National University,

Canberra, ACT 0200 .

Australia 